\title{
MENGEMBANGKAN PEMIKIRAN FALSAFAH PENDIDIKAN ISLAM
}

\author{
Mukhlis Fahruddin ${ }^{1}$
}

\begin{abstract}
Abstrak
Dichotomic paradigm in Islamic education has brought about some difficulties in responding challenges of change. This dichotomic prototype even caused the backthrough of Islamic civilization. In spite of this, new paradigm of Islamic scientific epistemology which develop integratic and interconected Islamic educational progress in the future is needed. The progress thoughts is needed in Islamic education to minimize disparity between science and religion.
\end{abstract}

Keywords: Epistemology, Philosophy, Development and Islamic education

\section{A. Pendahuluan}

Aktivitas kependidikan Islam di Indonesia pada dasarnya sudah berlangsung dan berkembang sejak sebelum Indonesia merdeka hingga sekarang. Hal ini dapat dilihat dari fenomena tumbuh kembangnya program dan praktek pendidikan Islam yang dilaksanakan di Nusantara; Pesantren, Madrasah, pendidikan umum yang bernafaskan Islam, dan beberapa model pendidikan baik informal maupun nonformal lainnya.

Fenomena tersebut menggaris bawahi adanya pemikiran tentang pengembangan pendidikan Islam di Indonesia dalam berbagai jenis dan bentuknya. Hanya saja, dikalangan para ahli masih terdapat pendapatpendapat yang kontroversial, terutama menyangkut kekokohan landasan filosofisnya. Di satu pihak ada yang menyatakan bahwa adanya kegiatan pendidikan Islam, sistem pendidikan Islam yang memiliki ciri-ciri tertentu, menunjukan adanya bangunan filosofis yang kokoh dari program dan praktek pendidikan Islam. (Muhaimain, 2003: 2)

1 Dosen Fakultas Sains Dan Teknologi Universitas Islam Negeri Maulana Malik Ibrahim Malang Jl. Gajayana No. 50 Malang 65144 
Dalam mengkaji filsafat, permasalahan yang sering muncul adalah kita hanya membahasnya dari aspek sejarah saja, sehingga kajian filsafat selalu 'datar-datar aja', tanpa mengambil substansi dari belajar sejarah filsafat. Filsafat juga tidak dijadikan sebagai pisau analisis dalam membedah problem mendasar manusia, sehingga kontribusi filsafat belum bisa dirasakan.

Dalam tulisan ini ingin mengkaji filsafat tidak hanya dari aspek sejarah saja, tetapi mengkaji kontribusi filsafat dalam kerangka pemikiran pendidikan Islam. Topik ini sangat penting untuk dibahas mengingat problem mendasar dalam pendidikan kita adalah ketidaktahuan dan ketidak konsistensian dalam mengarahkan peserta didik kearah dasar tujuan dari pendidikan tersebut. Sehingga sepertinya kita kehilangan orientasi, dan hal itu mengakibatkan ketidak maksimalan dalam proses pendidikan yang selanjutnya berakibat kepada mutu lulusan.

Kemunculan dan perkembangan tradisi keilmuan, pemikiran dan filsafat di dunia Islam tidak dapat dipisahkan dari kondisi lingkungan (peradaban dan kebudayaan) yang mengitarinya. Dengan kata lain bahwa tradisi intelektual dalam Islam bukanlah sesuatu yang orisinil dan baru sama sekali tetapi merupakan formulasi baru hasil perpaduan antara kebudayaan dan peradaban yang sudah ada dalam sistem sosial sebelumnya. Hal ini juga berarti bahwa ada kontinuitas dalam tradisi yang dikembangkan oleh Islam. Hal ini sangatlah logis, karena kehidupan manusia adalah ibarat mata rantai yang akan senantiasa berputar dan berhubungan satu dengan lainnya selama kehidupan di alam dunia ini masih berlangsung.

Seperti banyak diungkap oleh para sejarawan bahwa kemajuan dan pesatnya perkembangan kebudayaan dan peradaban di dunia Islam terjadi setelah adanya kontaks dengan kebudayaan dan peradaban barat (Yunani), yakni tepatnya pada masa pemerintahan khalifah Malik Ibn Marwan dari dinasti Bani Umayah yang berpusat di Damaskus (sekarang Negara Syiria). Perkembangan ilmu pengetahuan dan filsafat Islam mencapai puncaknya pada masa pemerintahan dinasti Bani Abbasiyah di Baghdad (Irak). Interaksi dan akulturasi yang terjadi antara kebudayaan Islam, Yunani dan Persia telah menciptakan tradisi intelektual yang sangat menggetarkan dunia.

Perkembangan ilmu pengetahuan dan filsafat di dunia Islam berlangsung selama kurang lebih enam abad, yakni dari abad ke-7 sampai abad ke-12 masehi. Kurun waktu ini telah memberikan kesempatan bagi para ilmuan 
untuk merumuskan dan menuangkan berbagai bentuk pemikiran dan perenungan kefilsafatannya dalam berbagai ruang kehidupan, termasuk dalam dunia pendidikan.

Ketika umat Islam mengalami puncak kejayaannya, bangsa barat saat itu masih berada dalam kegelapan (the dark age). Namun tidak lama kemudian merekapun bangun dari "tidurnya", dan berusaha meraih kejayaan seperti yang telah dicapai oleh umat Islam. Hukum alampun berlaku dan roda kehidupan-pun berputar. Puncak kejayaan intelektual yang dialami umat Islam dengan segala bentuknya yang memberikan manfaat langsung maupun tidak langsung bagi kehidupan, telah melengahkan mereka dari upaya mengembangkan dan melestarikannya. Konflik internal maupun eksternal yang dialami umat Islam telah melahirkan suatu slogan yang mematikan daya kreatifitas akal. Slogan itu berbunyi "pintu ijtihad telah tertutup". Dampak dari pemikiran ini adalah terjadinya stagnasi pemikiran umat Islam yang berakibat pada semakin rendahnya semangat intelektualisme dikalangan umat Islam, dan akhirnya kehidupan umat pun terpuruk!.

Ketika dunia Islam mengalami stagnasi dan kemunduran, dunia barat malah sedang mengalami masa pencerahan (enlightment era), yaitu dengan terjadinya renaisance (peralihan bangsa-bangsa Eropa dari zaman pwertengahan ke zaman modern yang muncul pada abad ke-14 di Italia dan berlanjut sampai abad ke-17) yang ditandai dengan pesatnya perkembangan sastra, seni dan ilmu pengetahuan modern.

Semangat renaisance dan implikasinya, disadari atau tidak, masih terasa sampai sekarang. Perkembangan ilmu pengetahuan dan teknologi menuntut manusia untuk selalu berupaya menemukan formulasi baru bangunan keilmuan yang akan bermanfaat langsung bagi kehidupan umat manusia.

\section{B. Pengertian Epistemologi}

Kata Epistemologi berasal dar bahasa Yunani "episteme" dan "logos". "Episteme" artinya pengetahuan (knowledge). "Logos" artinya teori. Dengan demikian kata epistemologi secara bahasa berarti teori pengetahuan. (Rizal Mustansyir dan Misnal Munir, 2006: 16) 
Epistemologi adalah cabang filsafat yang menyelidiki asal mula, susunan, metode-metode dan sahnya pengetahuan. Pertanyaan mendasar yang dikaji adalah; apakah pengetahuan itu?, apakah yang merupakan asal mula pengetahuan kita?, bagaimana cara kita mengetahui bila kita mempunyai pengetahuan?, Apakah yang merupakan bentuk pengetahuan itu?, bagaimanakah cara kita memperoleh pengetahuan?, apakah kebenaran dan kesesatan itu?, apakah kesalahan itu?. Secara umum pertanyaan diatas dikelompokkan menjadi dua, yaitu pertanyaan epistemologi kefilsafatan yang erat kaitannya dengan ilmu jiwa dan yang kedua adalah masalah semantik, yakni menyangkut hubungan antara pengetahuan kita dengan objek pengetahuan tersebut. Dari pengetian diatas dapat dipahami bahwa objek material epistemologi adalah pengetahuan, sedangkan objek formalnya adalah hakikat pengetahuan.

\section{Metode-Metode Untuk Memperoleh pengetahuan}

Sebelum membahas tentang metode-metode memperoleh pengetahuan, perlu dijelaskan terlebih dahulu bahwa semua pengetahuan hanya dikenal dan ada di dalam pikiran manusia, tanpa pikiran pengetahuan tidak akan eksis. Oleh karena itu keterkaitan antara pengetahuan dengan pikiran merupakan sesuatu yang kodrati. Archie Bahm menyebutkan delapan hal penting yang berfungsi membentuk struktur pikiran manusia, yaitu:

1. Observasi, pikiran berperan dalam mengamati objek-objek yang dijumpai.

2. Inquires, yaitu penyelidikan lebih lanjut terhadap objek-objek yang dijumpai.

3. Believes, yaitu kepercayaan atau keyakinan. Manakala suatu objek muncul dalam kesadaran, biasanya objek-objek itu diterima sebagai objek yang menampak. Penampakan eksistensi suatu objek itu dapat melahirkan suatu kepercayaan atau keyakinan tersendiri.

4. Desires, yaitu hasrat atau keinginan-keinginan. Kodrat hasrat ini mencakup kondisi-kondisi biologis dan psikologis dan interaksi dialektik antara tubuh dan jiwa.

5. Intends, yakni maksud. Seseorang melakukan pengamatan, penyelidikan, mempercayai dan memiliki hasrat terhadap sesuatu objek karena 
dilatarbelakangi oleh maksud-maksud tertentu.

6. Organizes, yaitu pengaturan. Setiap pikiran adalah suatu organisme yang teratur dalam diri seseorang melalui pengantisipasian, peramalan dan menjadikan kesadaran terhadap objek-objek yang diramalkan.

7. Adapts, yaitu penyesuaian. Kehidupan terdiri atas kesiapan untuk menghadapi persoalan secara terus menerus dan mencoba untuk memecahkannya. Proses menemukan solusi suatu masalah memerlukan penyesuaian-penyesuaian dan pembatasan terhadap pemikiran yang muncul.

8. Enjoys, yakni menikmati. Pikiran-pikiran mendatangkan keasyikan, dan orang yang asyik dalam menekuni suatu persoalan, maka ia akan menikmatinya dalam pikiran. Kesenangan dan kesusahan yang dialami seorang manusia itu sangat kompleks dan sulit untuk dipetakan secara pasti, namun dapat diketahui secara intrinsik melalui rasa senang dan rasa susah. (Rizal Mustansyir dan Misnal Munir, 2006: 18-22)

Kedelapan hal tersebut diatas senantiasa dialami oleh setiap manusia dalam

merespon suatu objek yang diamatinya. Oleh karena itu dalam memperoleh pengetahuan seseorang dapat melalui metode-metode berikut ini;

1. Empirisme, yaitu bahwa pengetahuan yang didapatkan oleh manusia diperoleh melalui pengalaman. Pengetahuan diperoleh dengan perantaraan indera. Jhon Locke (tokoh aliran empirisme) menyatakan bahwa ketika manusia dilahirkan tidak mengetahui apa-apa, akalnya seperti buku catatan yang kosong (tabula rasa) dan di dalam buku catatan itulah dicatat pengalaman-pengalaman inderawi seseorang sehingga terakumulasi menjadi pengetahuan yang dimilikinya.

2. Rasionalisme, yaitu suatu paham yang menyatakan bahwa pengetahuan yang diperoleh manusia bersumber dari akalnya. Tokoh aliran ini adalah Rene de Cartes yang mengajukan adagium “Cogito Ergo Sum”. Dalam aliran ini pengalaman hanya dipandang sebagai sejenis perangsang bagi akal pikiran untuk mengasosiasikan dan menilai objek yang dijumpainya. Dengan demikian, jika saya mengatakan bahwa saya melihat suatu pohon, maka saya tidak mempunyai pengetahuan, 
melainkan hanya pendapat, karena saya membuat pernyataan itu sebagai hasil penyimpulan yang diperoleh dari tangkapan indera penglihatan dan dari ingatan-ingatan tertentu yang saya punyai. Maka bagi seorang penganut rasionalisme, ukuran kebenaran adalah kemustahilan untuk mengingkari dan untuk dipahamkan yang sebaliknya.

3. Fenomelogi, Immanuel kant, seorang filsuf Jerman abad XVIII, melakukan pendekatan kembali terhadap masalah diatas setelah memperhatikan kritik-kritik yang dilancarkan oleh David Hume terhadap sudut pandang yang bersifat empiris dan rasional. Pendirian Kant dikenal sebagai "fenomenalisme" karena alasan-alasan seperti berikut ini;

a. Sebab akibat tidak dapat dialami. Kant memberikan ilustrasi bahwa indera hanya dapat emberikan data inderawi berupa warna, cita rasa, bau rasa dan sebagainya.

b. Pengetahuan diperoleh karena terjadinya hubungan antara akal dengan data inderawi yang diberikan kepadanya. Karena akal mempunyai bentuk-bentuk untuk mengalami, memahami serta berpikir, dan pengetahuan selalu terdapat dalam bentukbentuk ini. Oleh karena itu, menurut Kant pengetahuan itu ada empat macam, yaitu pengetahuan apriori (tidak tergantung pada pengalaman), pengetahuan aposteriori (tergantung pengalaman), pengetahuan analitis ( hasil analisa) dan pengetahuan sintesis ( hasil penggabungan unsur-unsur yang terpisah). Bagi Kant, para penganut empirisme benar bila berpendapat bahwa semua pengetahuan didasrkan pada pengalaman - meskipun benar hanya untuk sebagian. Para penganut rasionalime juga benar, karena akal memaksakan bentuk-bentuknya sendiri terhadap barang sesuatu serta pengalaman.

4. Intuisionisme, ketidak puasan terhadap penyelesaian yang diberikan oleh Kant melalui teori kompromi antara empirisme dan rasionalisme, telah melahirkan tanggapan baru dunia epistemologi, yaitu teori intuitif yakni pengetahuan yang diperoleh secara langsung oleh daya intuisi yang dimiliki oleh setiap manusia. Henry Bergson, seorang filsup Perancis modern mengatakan bahwa ada dua macam pengetahuan, 
yaitu pengetahuan diskursif (pengetahuan yang diperoleh melalui simbol-simbol yang mencoba mengatakan kepada kita tentang sesuatu) dan pengetahuan intuitif (pengetahuan langsung yang mutlak tanpa perantara). Unsur berharga dalam paham intuisionisme adalah kemungkinan adanya suatu bentuk pengalaman, disamping pengalaman yang dihayati oleh indera. Dengan demikian data yang dihasilkannya dapat merupakan bahan tambahan bagi pengetahuan disamping pengetahuan yang dihasilkan oleh penginderaan.

5. Metode ilmiah, yaitu suatu sarana untuk memperoleh pengetahuan melalui prosedur-prosedur tertentu yang sudah pasti yang digunakan dalam usaha memberikan jawaban atas pertanyaan-pertanyaan yang dihadapi oleh seorang ilmuan. Prosedur-prosedur yang harus ditaati dalam memperoleh pengetahuan melalui metode ilmiah meliputi; objektif, metodis, sistematik dan universal.

\section{Trend pemikiran epistemologi kontemporer}

Filsafat kontemporer - yang diawali dengan munculnya pragmatisme dan diteruskan oleh filsafat analitik - bersumber untuk sebagian atau keseluruhannya dari keprihatinan yang mendalam dengan persoalan yang terkait dengan logika linguistik. Para pemikir kontemporer ingin membangun kerangka pandangan epistemologi baru dan sepakat untuk keluar dari berbagai kesulitan cara pemecahan yang biasa dikemukakan oleh filsafat modern. Filsafat modern berupaya untuk meninggalkan pembedaan antara subjek-objek untuk memahami hakekat pengetahuan, karena para pendukung filsafat kontemporer lebih suka dengan asumsiasumsi bahwa pada kenyataannya kita benar-benar telah mempunyai pengetahuan lewat berbagai cara, dan pada dasarnya kita juga dapat benar-benar mengetahui dunia dan mempunyai pengetahuan apapun arti pengetahuan dimaksud. Persoalan filsafat kontemporer bukan pada pertanyaan apakah mungkin kita memperoleh pengetahuan. Persoalan terpokok adalah bagaimana menunjukkan cara-cara pengetahuan tersebut diperoleh, yakni syarat-syarat (condition) dan cara-cara (Procedures) untuk memperoleh pengetahuan tersebut. 
Dengan demikian, tugas utama pemikiran epistemologi kontemporer adalah bagaimana kita dapat keluar dan terhindar dari keraguan, ketidaktahuan (ignorance), dan mengganti kepercayaan (beliefs) yang masih mentah dan tidak didukung oleh data yang memadai dengan kepercayaan yang didukung oleh data yang bagus dan selengkap mungkin; bagaimana kita dapat membedakan kepercayaan yang sehat dan yang tidak sehat; bagaimana kita dapat mencapai kemajuan-kemajuan (progress) dalam ilmu pengetahuan, baik yang terkait dengan perluasan dan pengembangan ilmu pengetahuan maupun dalam hal penjernihan dan perbaikan kepercayaankepercayaan kita terhadap dunia dalam berbagai cabang dan bidangnya yang hampir-hampir tidak terbatas. (Amin Abdullah, 2006: 128).

Dari pernyataan diatas dapat dipahami bahwa epistemologi akan selalu bersentuhan dengan persoalan logika yang meliputi kemampuan berbicara (power of speech), kemampuan mengambil kesimpulan (Inference), kemampuan untuk menyusun pemikiran konseptual (Conceptual Thought), dan lebih-lebih lagi untuk melakukan penelitian yang rasional (rational inquiry). Persentuhan epistemologi dengan logika akan semakin memperluas ruang lingkup kajian kefilsafatan yang berimplikasi pada semakin luasnya cakrawala pemikiran epistemologis.

\section{E. Antara Filsafat dan Pendidikan}

Filsafat merupakan sebuah disiplin ilmu yang terkait dengan perihal kebijaksanaan yang merupakan titik ideal dalam kehidupan manusia. Karena ia dapat menjadikan manusia untuk bersikap dan bertindak atas dasar pertimbangan kemanusiaan yang tinggi (actus humanus), bukan asal bertindak sebagaimana yang biasa dilakukan manusia kebanyakan (actus homini). Kebijaksanaan tidak dapat dicapai dengan jalan biasa, ia memerlukan langkah-langkah tertentu, khusus dan istimewa, seperti; sikap kritis terhadap kepercayaan dan sikap yang selama ini dijunjung tinggi, mampu mensintesis berbagai pengetahuan dan pengalaman yang dimiliki, cermat dalam berfikir dan berusaha menemukan hikmah dibalik pengetahuan dan pengalaman hidupnya. Aktifitas filsafat melibatkan akal pikir manusia secara utuh, konsisten dan bertanggung jawab untuk mengungkap realitas melalui sarana-sarana yang dapat digunakan secara praktis dalam proses pengungkapan realitas tersebut. Mengingat luasnya 
bidang kaji ilmu filsafat, maka secara umum filsafat itu terbagi dua, yaitu filsafat umum atau murni dan filsafat khusus atau filsafat terapan.

Berbicara mengenai pendidikan maka kita tidak bisa terlepas dari dua tema besar yang melingkupinya, yaitu (1) praktek pendidikan dan (2) ilmu pendidikan sebagi suatu bentuk teori pendidikan yang meliputi berbagai konsep filosofis dan praktis yang dihasilkan melalui kerja ilmiah. Oleh karena itu, dilihat dari segi bentuknya filsafat pendidikan dalam arti luas dapat dibedakan menjadi dua macam, yaitu;

1. filsafat praktek pendidikan, yaitu analisis kritis dan komprehensif tentang bagaimana seharusnya pendidikan diselenggarakan dan dilaksanakan dalam kehidupan manusia. Filsafat praktek pendidikan dibagi menjadi dua yaitu filsafat proses pendidikan dan filsafat sosial pendidikan.

2. Filsafat ilmu pendidikan (Philosophy of educational Science), yaitu analitis kritis komprehensif tentang pendidikan sebagai salah satu bentuk teori pendidikan yang dihasilkan melalui riset, baik kuantitatif maupun kualitataif. (Redja Mudyahardjo, 2002: 6)

Dari penjelasan diatas jelaslah bahwa filsafat ilmu pendidikan adalah cabang dari filsafat ilmu. Dengan kata lain filsafat pendidikan yang meliputi filsafat praktek pendidikan dan filsafat ilmu pendidikan merupakan bentuk filsafat khusus atau filsafat terapan. Sebagai ilmu terapan maka filsafat ilmu pendidikan mempunyai objek formal sekaligus objek materialnya yang menjadi bidang lingkup garapan riset pendidikan.

Objek formal ilmu pendidikan adalah pendidikan dalam arti luas, sempit dan terbatas. Dalam pengertian yang luas pendidikan sama dengan hidup dengan segala situasi dan kondisi yang mempengaruhi pertumbuhan seseorang. Pendidikan adalah pengalaman belajar, oleh karenanya pendidikan dapat juga diartikan sebagai keseluruhan pengalaman belajar setiap orang sepanjang hidupnya. Pengalaman belajar yang diperolehnya tidak terbatas pada lingkungan sekolah, tapi berlangsung dalam segala bentuk lingkungan hidup manusia. Dalam pengertian yang sempit, pendidikan adalah sekolah atau persekolahan (schooling). Sekolah adalah lembaga pendidikan formal sebagai salah satu hasil rekayasa dari peradaban manusia, keluarga, dunia kerja, negara dan lembaga keagamaan. Dengan arti sempit ini maka proses 
pengalaman belajar yang didapatkan seseorang sangat terbatas dengan ruang dan waktu. Dan dalam pengetian luas terbatas pendidikan adalah usaha sadar yang dilakukan keluarga, masyarakat dan pemerintah melalui kegiatan bimbingan, pengajaran dan atau latihan yang berlangsung di sekolah maupun diluar sekolah untuk mempersiapkan peserta didik agar dapat memainkan peranan secara tepat dalam berbagai lingkungan hidup.

Objek material ilmu pendidikan terintegrasi dalam dua falsafah penting pendidikan, yaitu pendidikan sebagai sebuah sistem dan pendidikan seumur hidup. Sebagai sebuah sistem, pendidikan merupakan kegiatan yang menjembatani antara kondisi-kondisi aktual (kondisi lingkungan peserta didik, dimensi psikologis, sosiologis, antropologis, ekologis, teknologis, dll) dengan kondisi-kondisi ideal yang diharapkan (terwujudnya sosok manusia ideal yang mempunyai integritas moral, sosial, intelektual dan religiusitas yang tinggi) melalui suatu rangkaian proses pendidikan yang dilakukan secara sistematis dan terukur.

Selain mengelola proses-proses yang bersifat praksis dan bersentuhan langsung dengan rangkaian kegiatan pendidikan yang terlembagakan dalam institusi persekolahan, objek material ilmu pendidikan juga menyangkut persoalan-persoalan pendidikan yang lebih bersifat teori filosofis yang berusaha menjangkau lebih jauh hakekat proses pendidikan yang dilakukan.

Dave dalam Lifelong education and school curriculum (1973) mencoba menggambarkan kerangka kerja teoritis dan operasional pendidikan seumur hidup dalam empat tahap, yaitu; (1). Deskripsi komponen-komponen hidup, (2) deskripsi aspek-aspek dalam perjalanan sepanjang hidup, (3) deskripsi pendidikan dan (4) deskripsi sebuah sistem operasional pendidikan seumur hidup. (Redja Mudyahardjo, 2002: 79)

Secara singkat konsep pendidikan seumur hidup adalah sebuah konsep pendidikan yang mengintegrasikan tiga unsur utama kehidupan ( individu, masyarakat dan lingkungan fisik) secara harmonis. Pola-pola pendidikan yang diselenggarakan berupaya menanamkan kesadaran manusia terhadap tanggung jawab pemeliharaan alam semesta, sebab kehidupan akan terus berlangsung selama alam semesta masih ada. 


\section{F. Epistemologi dalam Pendidikan Islam}

Pendidikan Islam sebagi suatu proses pengembangan potensi kreatif peserta didik untuk menjadi manusia yang beriman dan bertakwa kepada Allah swt., berkepribadian, cerdas, terampil, memiliki etos kerja yang tinggi, berbudi luhur, mandiri dan bertanggung jawab terhadap diri, bangsa dan negara serta agama; telah berlangsung sepanjang sejarah kehidupan manusia. Namun jika dilihat dari dimensi ilmu dan filsafat, pendidikan Islam masih dipersoalkan keberadaannya.

Ada tiga komponen utama yang menjadi landasan bagi filsafat pendidikan Islam, yaitu filsafat manusia, filsafat ilmu dan filsafat nilai menurut pandangan Islam. Titik singgung dari ketiga filsafat diatas merupakan kawasan ontologis filsafat pendidikan Islam seperti yang terlihat pada gambar berikut.

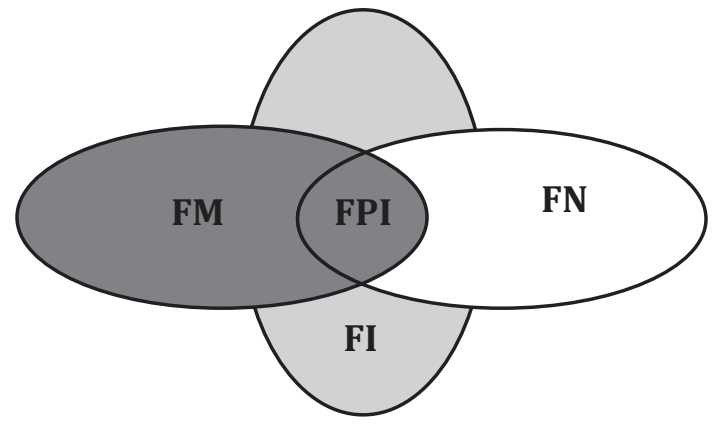

Dari tiga komponen ini pula lahir paradigma filosofis pendidikan Islam, diantaranya seperti yang diungkapkan oleh Noeng Muhadjir (1996: 203) bahwa setidaknya ada sepuluh prinsip dasar bagi pendidikan Islam, yaitu;

1. asumsi dasar dan landasan filosofik realisme metaphisik yang memandang keteraturan alam semesta adalah ciptaan Allah swt.

2. postulasi ontologiknya, bahwa keteraturan alam merupakan realitas kebenaran yang bersifat multi faset; yakni menerima eksistensi realitas empirik, sensual, empirik logik, empirik etik, dan empirik transedental yang sesuai dengan petunjuk, maupun isyarat dan hikmah yang berasal dari wahyu. 
3. postulasi aksiologiknya, ilmu pendidikan Islam adalah ilmu normatif oleh karena itu diorientasikan kepada values baik yang bersifat insaniyah maupun ilahiyah.

4. tesis epistemologiknya; (a) wahyu memiliki kebenaran mutlak; (b) kebenaran akal bersifat probabilitas; (c) tidak mengenal kebenaran ganda antara kebenaran empirik dengan kebenaran wahyu, melainkan hanya mengenal strata kebenaran yakni:

Transedental $\longrightarrow$ Hudan (rahmat)

Logik dan Etik $\longrightarrow$ Isyarat

Sensual $\longrightarrow$ Ayat

(d) menggunakan logika induktif probablistik untuk menjangkau yang tidak terkait dengan nilai; (e) menggunakan logika dan pembuktian deduktif probabalistik untuk menjangkau phenomena yang terkait dengan nilai; dan (f) menggunakan logika reflektif probabailistik untuk menangkap kebenaran wahyu yang bersifat mutlak.

Dari penjelasan diatas maka dapat ditarik suatu kesimpulan bahwa anggapan sebagian masyarakat yang mengatakan bahwa antara "agama" dan "ilmu" adalah dua entitas yang tidak bisa dipertemukan telah terbantahkan, karenanya perlu segera dikoreksi dan diluruskan. Karena sejatinya islam memandang antara agama dan ilmu ibarat dua sisi mata uang yang tidak dapat dipisahkan, keduanya saling menunjang dan melengkapi serta dapat digunakan untuk mewujudkan fungsi dan peran manusia sebagai khalifatullah fil ardh - duta Allah dimuka bumi yang bertugas untuk memakmurkan (memanfaatkan) alam semesta bagi kehidupan manusia.

Bila pola pikir yang serba bipolar-dikotomis ini tidak segera diluruskan maka semakin hari umat tidak akan menemukan kenyamanan dan 
kesejahteraan dalam hidupnya. Pola pikir dikotomis ini hanya akan menjadikan manusia semakin terasing dari nilai-nilai spiritualitas-moralitas, terasing dari dirinya sendiri, masyarakatnya dan dari lingkungan sekitarnya. Singkatnya akan terjadi dehumanisasi secara massif pada tataran kehidupan keilmuan maupun keagamaan. (Amin Abdullah, 2006: 94).

Sebaliknya dari keadaan diatas, maka praktik pendidikan Islam yang berorientasi pada pendekatan integralistik dan interkonektif perlu segera mendapat perhatian serius dari berbagai kalangan. Mengapa demikian?. Jawabnya tidak lain adalah karena proses globalisasi yang telah merambah ke berbagai sisi kehidupan umat manusia dengan segala dampak positif maupun negatifnya tidak akan mampu dijawab bila menggunakan pola pendidikan yang bipolar - dikotomis tersebut.

Tantangan di era globalisasi menuntut respon tepat dan cepat dari sistem pendidikan Islam secara keseluruhan. Jika kaum muslimin tidak hanya ingin sekedar survive ditengah persaingan global yang semakin tajam dan ketat, tetapi juga berharap mampu tampil di depan, maka re-orientasi pemikiran pendidikan Islam dan rekontruksi sistem dan kelembagaan pendidikan merupakan suatu keniscayaan.

Gerakan rapprochment (gerakan penyatuan dan reintegrasi epistemologi keilmuan) diharapkan mampu menjawab berbagai kegagalan dan ketimpangan proses pendidikan yang dilaksanakan selama ini, khususnya pada pendidikan Islam.

Pola pendidikan yang menekankan pada aspek integrasi dan interkoneksi epistemologi keilmuan saat ini sedang berusaha diterapkan pada dua Universitas Islam Negeri terkemuka di Indonesia (UIN Jakarta, UIN Malang dan UIN Yogyakarta). Dua lembaga ini sengaja dijadikan sebagai pilot project pengembangan paradigma baru pendidikan Islam ini, darinya diharapkan lahir para cendekiawan yang memiliki basis keilmuan yang integral dan berkepribadian yang inklusif.

Lahirnya paradigma baru bagi pengembangan pendidikan Islam di Indonesia tidak lain adalah hasil dari pengembangan filsafat epistemologi keilmuan yang semakin dikaji secara kritis. Paradigma keilmuan baru yang menyatukan, bukan sekedar menggabungkan wahyu Tuhan dengan temuan pikiran manusia (ilmu-ilmu holistik integralistik), tidak akan berakibat 
mengecilkan peran Tuhan (seperti yang dipikirkan para penganut paham sekulerisme), atau akan mengucilkan manusia dari lingkungan sekitarnya, tetapi diharapkan konsep ini akan dapat menyelesaikan konflik antar sekulerisme ekstrim dan fundamentalisme negatif agama-agama yang rigid dan radikal dalam banyak hal.

\section{G. Membangun Tradisi Keilmuan Pendidikan Islam}

Jika kita perhatikan masa kejayaan Islam, tentunya hal yang menarik kita perhatikan adalah tradisi keilmuan masyarakat Islam pada waktu itu. Kesadaran akan ilmu dan kecintaan akan ilmu sangat tinggi, tradisi yang berkembang pada waktu itu adalah tradisi membaca, menulis, berdiskusi, keterbukaan/kebebasan berfikir, penelitian serta pengabdian mereka akan keilmuan yang meraka kuasai.

Tradisi itu terlihat dari; kecintaan mereka akan buku-buku yang hal itu dibarengi dengan adanya perpustakaan-perpustakaan baik atas nama pribadi yang diperuntukkan kepada khalayak umum atau yang disponsori oleh khalifah, para ulama biasanya open hause bagi siapa aja yang mau datang kerumahnya untuk membaca, kedudukan meraka juga dimata masyarakat sangat mulia. Sedemikian cintanya masyarakat akan ilmu sampai-sampai khalifah pada waktu itu untuk merebut hati masyarakat harus memberi perhatian kepada pengembangan ilmu. Kebebasan berpikir yang tinggi memicu tradisi berdiskusi dan berdebat, meraka menjadikan perpustakaan dan masjid sebagai tempat bertemu untuk berdiskusi. kebutuhan untuk berkarya, sehingga kemandekan pemikiran bisa diatasi.

Tradisi keilmuan ini juga telah berkembang di tradisi keilmuan barat; motivasi mereka sangat tinggi untuk mencari ilmu, tradisi membaca dan berdiskusi tinggi, tradisi meneliti yang tinggi, keterbukaan berfikir dan kebutuhan untuk berkarya juga sangat tinggi. Teknologi dan informasi kebanyakan dikuasai oleh barat, banyak temuan dan peraih nobel pengetahuan bukan dari kalangan Islam. Inilah menurut penulis kemajuan barat dan Islam abbasiyah dalam hal ilmu pengetahuan yang perlu kita kembangkan dalam rangka kemajuan dibidang pendidikan Islam. Inilah yang harus kita lakukan untuk mengejar ketertinggalan. Kita harus membangun tradisi keilmuan yang kondusif dalam lingkungan masyarakat akademis. 
Menciptakan tradisi membaca, tradisi menulis, berdiskusi, meneliti, keberanian untuk berfikir kreatif dan terbangunnya kebutuhan akan berprestasi dan berkarya.

Probem pendidikan Islam adalah problem sistemik, kita perlu melibatkan berbagai pihak untuk bisa lepas dari keterpurukan. Mulai dari pemerintah sebagai pembuat kebijakan besarbagi sistem pendidikan nasional dan sebagai pengayom pelaksanaannya, lembaga pendidikan Islam, pendidik, peserta didik sampai kepada orang tua pendidik (anak didik) .

Tradisi atau iklim akademis yang kondusif perlu didukung oleh berbagai pihak dari mulai kebijakan pemerintah yang mampu menyediakan fasilitas pendidikan yang memadai, fasilitas bisa berupa sarana praktikum, buku dan gedung yang kondusif untuk sarana belajar dan akses pendidikan untuk warga miskin. Pemerintah harus cermat dalam menentukan anggaran pendidikan serta mengawalnya, sehingga tidak ada penyelewengwan anggaran pendidikan yang hal itu memperngaruhi pelaksanaan program pendidikan.

Bagi lembaga sekolah dan pendidik harus mampu memberikan kebijakan dalam rangka membentuk tradisi intelektul (membaca, menulis, meneliti dan berdikusi serta berkarya) di kampus atau disekolah, misalnya dengan mengadakan lomba karya tulis ilmiah, lomba penelitian, lomba debat, memberikan motivasi untuk membaca, menggunakan metode dan media yang bisa mengembangkan daya pikir, kreatifitas, membuat program-program lainya untuk pengembangan diri dan menciptakan lingkungan yang kondusif untuk belajar.

Bagi orang tua membantu menciptakan suasana akademis dirumah, dengan mengarahkan meraka untuk belajar dan selalu memotivasi meraka untuk maju. Orang tua juga berkewajiban mengawasi prilaku anak didik, orang tua juga harus mengetahui program sekolah, sehingga kegiatan sekolah terbantu oleh orang tua ketika mereka berada diluar sekolah. Antara sekolah (lembaga Pendidikan Islam), guru (pendidik) dan orang tua anak didik harus saling komunikasi; Sekolah mengetahui kebutuhan masyarakat dan masyarakat mengetahui kebutuhan sekolah, mengetahui problem anak didik dan sebagainya. Hal ini memungkinan untuk mengetahui dan selanjutnya membicarkan problem-prolem pendidikan yang sedang terjadi, sehingga ditemukan solusi yang tepat untuk berbagai pihak 
Pengembangan tradisi-tradisi keintelektualan seperti diatas harus dikembangkan mulai dari pendidikan dasar. Jika tradisi tersebut tidak dikembangkan dari pendidkan dasar, maka pendidik akan kesulitan menciptakan tradisi keilmuan untuk mereka, sehingga penciptaan tradisi itu selalu terlambat untuk diterapkan.

\section{H. Learning Society; Upaya Memberdayakan Pendidikan Masyarakat.}

Keprihatikan bangsa ini yang dilanda krisis multidimensi dalam berbagai aspek kehidupan menuntut peran pendidikan Islam sebagai benteng sekaligus mencetak generasi penerus untuk memperbaiki kondisi yang ada. Menjadi sangat wajar jika beban dari krisis ini seluruhnya dibebankan kepada pendidikan. Baiknya suatu bangsa bisa dilihat dari baiknya pendidikannya, majunya suatu bangsa juga dipengaruhi dari pendidikannya.

Persepsi masyarakat terhadap sekolah mewakili kondisi yang ada dalam masyrakat/negara. Kenyataan ini, misalnya, telah pula mendapat perhatian para filosof sejak zaman Plato dan Aristoteles, sebagaimana diungkapkan bahwa 'as is the state, so is the shool' (sebagaimana negara, seperti itulah sekolah), atau 'what you want in the state, you put into school' (apa yang anda inginkan dalam negara, harus anda masukkan dalam sekolah). (Azzumardi Azra, 1999, dalam Samsul Nizar, 2002: 16) Hal ini menunjukan, bahwa keberhasilan dari proses pendidikan tidak hanya dipengaruhi oleh pihak sekolah saja, tetapi peran keluarga dan masyarakat juga berpengaruh terhadap keberhasilan pendidikan. Berangkat dari hal inilah maka perlu diperhatikan lingkungan di luar sekolah, baik secara formal maupun non formal, bahkan informasi sekaligus. Harus ada upaya menciptakan lingkungan yang kondusif, yang mampu mengembangkan potensi masyarakat guna mewujudkan tujuan pendidikan yang disepakati bersama.

Pengembangan pendidikan di Indonesia, hendaknya dilihat sebagai suatu proses kelangsungan peradaban bangsa, maka faktor-faktor psiko sosial budaya perlu diikutsertakan dalam merancang pendidikan, dan perlu diciptakan situasi yang kondusif dalam pembelajaran. Tranformasi sosial 
psikologis dan budaya adalah suatu keniscayaan yang dihadapai bangsa ini, tetapi hal itu bisa dikendalaikan, khususnya dalam sektor pendidikan. Transformasi ini memunculkan tatanan baru dalam masyarakat, untuk itu perlu pendekatan sejenis sosial and culture engenering yang mampu mengendalaikan perubahan dan pergeseran ke arah yang diinginkan. (Azzumardi Azra, 1999, dalam Samsul Nizar, 2002: 186)

Dalam upaya menciptakan situasi kondusif bagi keberhasilan belajar hanya dapat terjadi bila seluruh masyarakat kita menuju masyarakat learning society. Artinya, proses mencerdaskan kehidupan bangsa seperti yang diamanatkan oleh UUD 1945 hendaknya diselenggarakan melalui tiga jalur institusi pendidikan, yaitu; (1) lingkungan atau jalur sekolah dan jalur luar sekolah, (2) dilaksanakan oleh berbagi pihak termasuk kerjasama masyarakat dengan pemerintah. (3) merupakan kegiatan yang tidak terputus-putus higga dapat disebut sebagai pendidikan seumur hidup (life long education). (Azzumardi Azra, 1999, dalam Samsul Nizar, 2002: 186) Salah satu usaha yang dapat dilakukan untuk mewujudkan masyarakat belajar adalah dengan memberdayakan keluarga agar menjadi keluarga yang gemar belajar. Dalam memberdayakan pendidikan keluarga, relevan untuk ditampilakan beberapa fungsi keluarga, yaitu: (a) fungsi keagamaan, (b) fungsi cinta kasih, (c) fungsi reproduksi, (d) fungsi ekonomi, (e) fungsi pembudayaan, (f) fungsi perlindungan, (g) fungsi pendidikan dan sosial, dan (h) fungsi pelestarian lingkungan. (Azzumardi Azra, 1999, dalam Samsul Nizar, 2002: 188)

Disamping memberdayakan pendidikan keluarga, upaya mewujudkan learning society adalah dengan menciptakan partisipasi masyarakat, mewujudkan pendidikan yang berasal dari masyarakat, oleh masyarakat, untuk masyarakat. Dengan pendekatan demikian diharapkan akan mempertebal rasa self of belonging yang akhirnya tumbuhnya rasa tanggung jawab atas kondisi yang ada. Sehingga dengan learning society diharapkan akan terwujud masyarakat madani (civil society), hal ini sekaligus sebagai alternatif dalam mengatasi masalah yang melanda negara ini. 


\section{Penutup}

Dari uraian singkat dan sederhana ini ada beberapa pokok pikiran yang dapat kita ambil, yaitu; paradigma pendidikan Islam yang selama ini dikembangkan oleh umat Islam (paradigma bipolar-dikotomis) yang memisahkan antara ilmu dan agama telah menyebabkan banyak ketimpangan dan ketidakmampuan dalam merespon tantangan zaman. kesadaran untuk mengubah paradigma epistemologi keilmuan dalam pendidikan Islam dimaksudkan untuk memformat ulang pola proses pendidikan yang selama ini ada dengan cara-cara yang lebih baik dan responsible terhadap perkembangan zaman. arah baru paradigma epistemologi keilmuan pendidikan Islam yang dikembangkan (paradigma integralistik-interkonektif ) memberi setitik harapan bagi perkembangan dan kemajuan pendidikan Islam di masa yang akan datang.

\section{Daftar Pustaka}

Abdullah, M. Amin, Islamic studies di Perguruan Tinggi - Pendekatan Integratif -Interkonektif (Yogyakarta: Pustaka Pelajar, 2006) , cet. I.

Abdullah Idi dan Toto Suharto, Revitalisasi Pendidikan Islam (Yogyakarta: Tiara Wacana, 2006), cet. I

Al-Toumy Al- syaibani, Omar Muhammad, Falsafah Pendidikan Islam (Jakarta: Bulan Bintang, 1979), cet. I.

Kattsoff, Louis O., Pengantar filsafat, terjemah Soejono soemargono (Yogyakarta: Tiara Wacana, 2004), cet. IX.

Kuntowijoyo, Islam sebagai Ilmu- Epistemologi, Metodologi dan Etika (Bandung: Teraju, 2004) cet. I.

Ludjito, Ahmad, et.all., Reformulasi Filsafat Pendidikan Islam (Yogyakarta: Pustaka Pelajar, 1996), cet. I.

Nizar, Samsul, Filsafat Pendidikan Islam- Pendekatan Historis, teoritis dan Praktis (Jakarta: Ciputat Press, 2002), cet. I.

Mudyahardjo, Redja, Filsafat Ilmu Pendidikan (Bandung: Remaja Rosdakarya, 2002), cetakan II. 
Muntasyir, Rizal dan Munir, Misnal, Filsafat Ilmu (Yogyakarta: Pustaka Pelajar, 2006), cetakan V.

Mas'ud, Abdurrachman, et.all., Paradigma Pendidikan Islam (Yogyakarta: Pustaka Pelajar, 2001), cetakan I.

Tafsir, Ahmad, Filsafat Umum (Bandung : Remaja Rosdakarya, 2003), cetakan XII 
